\title{
POST-MENOPAUSAL VAGINITIS
}

\author{
Constance A. C. Ross \\ Microbiology Laboratory, Ayrshire Central Hospital, Irvine KA12 8SS
}

FROM puberty to the menopause the acidic secretion of the vagina has a moderate bactericidal effect (Wilson and Miles, 1975). During this period yeasts and Trichomonas vaginalis are the common causative organisms of vaginitis and except in the puerperium bacterial infection is rare. After the menopause the vaginal secretion is alkaline and the epithelium becomes thin, atrophic and easily traumatised and it has been considered that post-menopausal women are more liable than women of childbearing age to suffer from bacterial vaginitis. Thus, vaginal swabs sent to the laboratory from women over 50 years old with vaginitis are examined not only for yeasts and $T$. vaginalis but also for bacteria. However, the aetiological role of many of the bacteria isolated from vaginal secretions in these women is often uncertain as the normal flora is so varied.

The purpose of the present study was to compare the organisms isolated by a diagnostic laboratory from a series of post-menopausal women complaining of vaginal discharge with those from a group of normal post-menopausal women attending a cytology clinic.

\section{MATERIALS AND METHODS}

Swabs. The study was based on all vaginal swabs received by the laboratory from patients (383) over 50 years old with vaginal discharge attending hospitals, surgeries or clinics in Ayrshire during the 12-month period commencing June 1975. Patients attending venereal disease clinics were excluded from the study. Control vaginal swabs were obtained from all the women (148) over 50 years of age attending a cytological clinic during the same period. Charcoal-coated swabs were used, each being immersed in Stuart's medium for transport to the laboratory.

Culture methods. The culture media employed were blood agar incubated aerobically and anaerobically, MacConkey's agar, Sabouraud's agar for yeasts, and Feinberg-Whittington's medium (Feinberg and Whittington, 1957) for $T$. vaginalis. Cultures were incubated for $18-24 \mathrm{~h}$ at $37^{\circ} \mathrm{C}$, inspected for growth, and then reincubated for a further $24 \mathrm{~h}$. Only those organisms generally accepted as potential vaginal pathogens were reported (table), and then only when present as a heavy growth on one of the culture plates.

\section{RESULTS}

The organisms reported from the 383 women with vaginal discharge and the 148 women from whom control swabs were obtained are shown in the table. There was no significant difference between the organisms reported from the two groups of women except that yeasts were obtained from $20 \%$ of the former but from only $6 \%$ of the latter $\left(\chi^{2}=19.6 ; P<0.001\right)$.

Group A streptococci-well recognised as a cause of puerperal fever-were not detected in any of the control swabs, but were found in nine ( $2 \%$ ) of the swabs from women with discharge, the difference being not significant $\left(\chi^{2}=2 \cdot 3 ; P>0 \cdot 1\right)$.

\section{Discussion}

The findings of this study suggest that in general the only useful microbiological examination for post-menopausal women with vaginitis is that for yeasts. However, examination for $T$. vaginalis should also be done as in younger women it is a well-recognised vaginal pathogen. Although yeasts and $T$. vaginalis may be commensals in the vagina, their isolation from a woman with vaginal discharge warrants a course of antimicrobial therapy.

Considerable time and expense would be saved by limiting the microbiological examina-

Received 9 Sept. 1977; accepted 9 Nov. 1977.

J. MFD. MICROBIOL.-VOL. 11 (1978) 
TABLE

Micro-organisms cultured from vaginal swabs of post-menopausal women, with and without vaginitis

\begin{tabular}{|c|c|c|}
\hline \multirow[b]{2}{*}{ Organisms } & \multicolumn{2}{|c|}{ Number (and percentage) of } \\
\hline & $\begin{array}{l}383 \text { women with vaginitis } \\
\text { that yielded heavy growth } \\
\text { of the stated organisms }\end{array}$ & $\begin{array}{l}148 \text { normal women } \\
\text { that yielded heavy growth } \\
\text { of the stated organisms }\end{array}$ \\
\hline $\begin{array}{l}\text { Enterobacteriaceae } \\
\text { Streptococcus faecalis } \\
\text { Group A streptococci } \\
\text { Group B streptococci } \\
\text { Group G streptococci } \\
\text { Other streptococci } \\
\text { Staphylococcus aureus } \\
\text { Clostridium welchii } \\
\text { Bacteroides spp. } \\
\text { Yeasts } \\
\text { Trichomonas vaginalis }\end{array}$ & $\begin{array}{l}78(20) \\
27(7) \\
9(2) \\
19(5) \\
2(1) \\
26(7) \\
23(6) \\
5(1) \\
8(2) \\
77(20) \\
17(4)\end{array}$ & $\begin{array}{l}35(24) \\
21(14) \\
0(0) \\
15(10) \\
7(5) \\
13(9) \\
7(5) \\
4(3) \\
8(5) \\
9(6) \\
3(2)\end{array}$ \\
\hline
\end{tabular}

tion of patients with post-menopausal vaginitis to a search for yeasts and $T$. vaginalis. This policy might also help the clinician, as the reporting of what are probably normal bacterial inhabitants of the vagina, and their antibiotic sensitivities, tends to encourage an unnecessary use of antibiotics; such use might stimulate the growth of yeasts and make matters worse. Furthermore, a report that states " no significant growth" and at the same time mentions the isolation of normal vaginal inhabitants is often confusing to the doctor and occasionally to the patient (Kilmartin, 1977).

Quantitative assessments of viable bacteria in vaginal secretions might on occasion suggest that a commensal has become a pathogen. However, in most specimens from patients with vaginitis a mixed normal bacterial flora is obtained and quantitative assessments are therefore of little value. In certain conditions, such as post-operative gynaecological infections, a normal inhabitant of the vagina, e.g., a species of Bacteroides, may invade traumatised tissues and cause endogenous infection (Willis et al., 1974); a heavy growth of a normal inhabitant may in such an instance be worth reporting.

\section{SUMMARY}

The organisms cultured from the vaginal swabs of 383 women over 50 years old with vaginal discharge were compared with those from 148 normal women of similar age attending a cytology clinic. The only significant difference was that yeasts were found in $20 \%$ and $6 \%$ of the two groups of women, respectively. It is therefore concluded that in post-menopausal women with vaginal discharge, the main microbiological requirement is for the diagnosis and treatment of yeast infection.

I wish to thank the technical staff of this laboratory for their co-operation and Dr Mary Armitage for collecting specimens from the normal women.

\section{REFERENCES}

Feinberg, J. G. AND Whittington, M. J. 1957. A culture medium for Trichomonas vaginalis Donne and species of Candida. J. clin. Path., 10, 327.

Kilmartin, A. 1977. For love of a swab. Wld Med., 12, No. 10, 112.

WILlis, A. T. et al. 1974. Metronidazole in the prevention and treatment of bacteroides infections in gynaecological patients. Report by a study group. Lancet, 2, 1540.

Wilson, G. S. AND Miles, A. A. 1975. Topley and Wilson's Principles of bacteriology, virology and immunity, 6th ed., London, vol. 2, p. 2617. 